\title{
PERAN GUGUS TUGAS REFORMA AGRARIA DALAM PELAKSANAAN REFORMA AGRARIA DI KABUPATEN LAMPUNG TENGAH
}

\author{
Zahril Trinanda Putra ${ }^{1 *}$, Aristiono Nugroho ${ }^{2}$, Ahmad Nashih Luthfi $^{2}$ \\ ${ }^{1}$ Kantor Pertanahan Kota Dumai Provinsi Riau \\ ${ }^{2}$ Sekolah Tinggi Pertanahan Nasional \\ Jalan Tata Bhumi No 5 Banyuraden, Gamping, Sleman, Yogyakarta \\ $1^{*}$ Corresponding author: zahril.trinanda.putra@gmail.com
}

Vol 1, No. 1
April 2021
Received
April $30^{\text {th }} 2021$
Accepted
May $25^{\text {th }} 2021$

\begin{abstract}
The implementation of agrarian reform to date has not been maximized due to the existence of sectoral egos and lack of coordination between related sectors / ministries. The institutional formation of the GTRA is expected to be able to unite across sectors of the relevant ministries / institutions. In Central Lampung Regency there are many land issues on HGU land and transmigration land which will later become the priority location of the Agrarian Reform Land (TORA). The Central Lampung BPN target in 2020 as many as 3,000 plots of land will be distributed to the public. It is hoped that the existence of GTRA can support the achievement of these targets. This study aims to determine the role of GTRA, obstacles and how to overcome obstacles in implementing agrarian reform in Central Lampung Regency. The research method used is qualitative with a descriptive approach. The results showed that budget limitations and the existence of an institutional sectoral ego led to impeded implementation of asset management and access structuring. A strong commitment from all GTRA implementers is needed in carrying out all agrarian reform programs. If not, the GTRA will be the same as the previous institution which only changed its name.
\end{abstract}

Keywords: Agrarian Reform, GTRA, TORA.

\section{INTISARI}

Pelaksanaan reforma agraria sampai saat ini belum maksimal dikarenakan adanya ego sektoral dan kurangnya koordinasi antara lintas sektor kementerian/lembaga terkait. Pembentukan kelembagaan Gugus Tugas Reforma Agraria (GTRA) diharapkan mampu menyatukan lintas sektor kementerian/lembaga terkait. Di Kabupaten Lampung Tengah terdapat banyak permasalahan tanah pada tanah HGU dan tanah transmigrasi yang nantinya dijadikan lokasi prioritas Tanah Objek Reforma Agraria (TORA). Target BPN Kabupaten Lampung Tengah tahun 2020 sebanyak 3.000 bidang tanah akan direditribusikan ke masyarakat. Harapannya dengan adanya GTRA dapat mendukung capaian target tersebut. Penelitian ini bertujuan untuk mengetahui peran GTRA, kendala dan cara mengatasi kendala dalam pelaksanaan reforma agraria di Kabupaten Lampung Tengah. Metode penelitian yang digunakan adalah kualitatif dengan pendekatan deskriptif. Hasil penelitian menunjukan bahwa keterbatasan anggaran dan adanya ego sektoral kelembagaan menyebabkan terhambatnya pelaksanaan penataan aset dan penataan akses. Dibutuhkan komitmen yang kuat dari seluruh pelaksana GTRA dalam menjalankan seluruh program reforma agraria. Jika tidak maka GTRA akan sama saja dengan kelembagaan sebelumnya yang hanya berganti nama.

Kata Kunci: Reforma Agraria, GTRA, TORA.

\section{A. Pendahuluan}

Pemerintahan Joko Widodo-Jusuf Kalla menempatkan reforma agraria sebagai salah satu program prioritas nasional dan menuangkannya ke dalam Rencana Pembangunan Jangka Menengah Nasional (RPJMN) 2015-2019. Pelaksanaannya diatur lebih jauh dalam Peraturan Presiden Nomor 45 Tahun 2016 tentang Rencana Kerja Pemerintah (RKP) Tahun 2017. Dari Peraturan Presiden Nomor 45 Tahun 2016, 
kemudian 9 juta hektar lahan negara ditetapkan menjadi target redistribusi dan legalisasi aset di bawah payung reforma agraria yang sumbernya dari kawasan hutan dan luar kawasan hutan (perkebunan). Selanjutnya pemerintahan Jokowi mengeluarkan Peraturan Presiden Nomor 86 Tahun 2018 tentang Reforma Agraria untuk menjalankan agenda prioritas nasional tersebut.

Pelaksanaan reforma agraria dari masa ke masa di Indonesia telah dilaksanakan, akan tetapi ketimpangan penguasaan dan pemilikan tanah serta konflik agraria masih ada bahkan cenderung bertambah. Reforma agraria di Indonesia diarahkan untuk melakukan perubahan struktur penguasaan, pemilikan, penggunaan dan pemanfaatan tanah untuk menjamin terwujudnya keadilan dan kepastian hukum dalam penguasaan, pemilikan, penggunaan dan pemanfaatan tanah (Nurlinda 2009). Wiradi (2000, 181-182) mengatakan salah satu syarat kesuksesan pelaksanaan reforma agraria adalah kemauan elit politik penguasa, dalam hal ini presiden memadukan secara lintas sektor/kementerian pelaksana kebijakan. Adapun caranya dengan membentuk suatu kelembagaan pelaksana reforma agraria di pusat dan daerah. Kantor Staf Presiden (2016) menyatakan pembentukan kelembagaan pelaksana reforma agraria di pusat dan daerah bertujuan untuk memastikan tersedianya dukungan kelembagaan di pemerintah pusat dan daerah serta memampukan desa untuk mengatur penguasaan, pemilikan, penggunaan dan pemanfaatan tanah.

Secara substantif, era pemerintahan Joko Widodo dan Jusuf Kalla (Jokowi-JK) tidak lagi mendefinisikan reforma agraria secara sempit, yakni pengaturan kembali atau perombakan dan penataan struktur penguasaan tanah dengan pendekatan redis hak milik, akan tetapi reforma agraria ditempatkan sebagai strategi pembangunan Indonesia secara luas dengan pendekatan akses (Salim \& Utami, 2019). Capaian fisik kegiatan redistribusi tanah di Kementerian ATR/BPN tahun 2019 sebanyak 668.715 bidang $(86,82 \%)$ dari target sejumlah 770.237 bidang, berasal dari tanah eks-HGU, tanah terlantar dan tanah negara lainnya, serta pelepasan kawasan hutan. Adapun target tahun 2020 sebanyak 602.135 bidang di 34 provinsi (kecuali DKI Jakarta dan DIY) di Indonesia, dengan prioritas untuk tanah pertanian dan sebagian tanah non pertanian (Direktorat Jenderal Penataan Agraria 2020). Untuk mewujudkan capaian tersebut tentunya dibutuhkan kelembagaan yang mampu mendukung kegiatan redistribusi tanah di Kementerian ATR/BPN. GTRA mempunyai tugas mengkoordinasikan, mengusulkan dan merekomendasikan lokasi-lokasi yang berpotensi menjadi TORA yang selanjutnya akan diredistribusikan kepada masyarakat sesuai dengan ketentuan yang berlaku. Harapannya dengan adanya GTRA target yang sudah ditetapkan oleh pemerintah bisa dipenuhi.

Kabupaten Lampung Tengah adalah salah satu kabupaten yang telah membentuk GTRA di tingkat kabupaten. Ukuran lahan yang luas serta masih banyak tanah yang belum bersertifikat maupun tanah yang belum memiliki kepastian pemilikan menjadikan Kabupaten Lampung Tengah daerah yang memiliki potensi TORA yang besar. Selain itu, banyak juga permasalahan pertanahan terkait tanah HGU yang dikuasai masyarakat maupun dari pihak HGU yang menduduki tanah masyarakat banyak terjadi di Kabupaten Lampung Tengah. Hal ini disebabkan karena distribusi 
tanah yang tidak merata di Kabupaten Lampung Tengah. Kemudian juga terdapat permasalahan terkait dengan tanah-tanah transmigrasi. Sebagai contoh tanah transmigrasi yang masuk kawasan hutan di SP. 3, tanah transmigrasi yang tidak terdaftar di Dinas Tenaga Kerja di Desa Sumber Agung dan Sidodadi serta ada juga masyarakat transmigrasi yang belum mendapatkan jatah lahan pertanian di Desa Sri Mulyo. Belum lagi masalah turunan yang muncul akibat masalah utama menambah berat permasalahan pertanahan di Kabupaten Lampung Tengah. Peran GTRA Kabupaten Lampung Tengah diharapkan mampu menyelesaikan persoalan-persoalan tersebut melalui reforma agraria mengingat lokasi-lokasi tersebut merupakan potensi TORA berdasarkan Peraturan Presiden Nomor 86 Tahun 2018.

Shohibuddin dkk. (2007) dengan laporan penelitian pelaksanaan uji coba Program Pembaharuan Agraria Nasional (PPAN) di Provinsi Lampung menyebutkan bahwasannya keberhasilan pelaksanaan reforma agraria juga memerlukan kelembagaan yang tangguh guna dapat menyelenggarakan tahapan perencanaan, pelaksanaan dan pengendalian rangkaian kegiatan reforma agraria secara terpadu. Kemudian, Atim (2008) juga melaksanakan penelitian mengenai pelaksanaan reforma agraria di Provinsi Lampung Tahun 2007. Hasilnya Pelaksanaan reforma agraria di Provinsi Lampung tidak melakukan penataan penguasaan dan pemilikan tanah karena reforma agraria tahun 2007 di Provinsi Lampung mencakup wilayah yang sempit. Selanjutnya, Luthfi (2018) mengkaji mengenai reforma kelembagaan dalam kebijakan reforma agraria Era Joko Widodo-Jusuf Kalla, yang hasilnya menyatakan bahwa strategi pelaksanaan Reforma Agraria ala Jokowi-JK melalui dua gerbang yaitu dengan Perhutanan Sosial dan Reforma Agraria.

Beberapa kajian diatas cukup menarik namun kajian mereka belum masuk secara detail mengenai isu kelembagaan GTRA yang hadir setelah terbitnya Peraturan Presiden Nomor 86 Tahun 2018 tentang reforma agraria. Kajian ini akan fokus pada persoalan kelembagaan GTRA, kendala dan cara mengatasi kendala dalam pelaksanaan reforma agraria di Kabupaten Lampung Tengah. Selanjutnya peneliti juga akan menganalisis dengan pemikiran-pemikiran lain, temuan, perspektif dan teori-teori serta peraturan yang ada untuk mendapatkan kesimpulan.

\section{B. Metode Penelitian}

Metode penelitian yang digunakan adalah penelitian kualitatif dengan pendekatan deskriptif. Sebagai penelitian kelembagaan, dikumpulkan informasi mengenai batas dan peluang kelembagaan yang tersedia saat ini berupa Gugus Tugas Reforma Agraria. Informasi diperoleh dari dokumen tertulis, foto dan wawancara. Metode penelitian kualitatif ini digunakan untuk mendeskripsikan mengenai peran GTRA dalam pelaksanaan reforma agraria. Data yang dikumpulkan kemudian dikategorisasi, diolah dan dianalisa ke dalam beberapa persoalan sebagai berikut: permasalahan aset, pelepasan tanah bekas perkebunan dan legalisasi tanah-tanah transmigrasi, penyelesaian konflik, kendala pelaksanaan dan solusi atas kinerja GTRA di Kabupaten Lampung Tengah, serta problematika antara GTRA dan PPL. 


\section{Peran GTRA Kabupaten Lampung Tengah \\ 1. Kegiatan GTRA Kabupaten Lampung Tengah}

Pelaksanaan reforma agraria dari masa ke masa telah dilaksanakan namun dalam pelaksanaannya masih belum maksimal. Ada dua faktor yang menyebabkan pelaksanaan reforma agraria masih belum maksimal. Pertama, belum adanya kelembagaan yang secara khusus untuk menjalankan dan mengembangkan agenda, program, dan kegiatan reforma agraria. Pada masa pemerintahan orde lama dan orde baru pelaksanaan reforma agraria hanya sebatas program pemerintah. Panitia Pertimbangan Landreform yang dibentuk pada orde lama juga belum mampu mengatasi permasalahan kemiskinan dan akses lapangan pekerjaan. Baru pada masa pemerintahan Susilo Bambang Yudhoyono dengan Program Pembaruan Agraria Nasional (PPAN) akan membentuk suatu kelembagaan pengelola reforma agraria yang mengurus, merencanakan dan memberdayakan penerima objek landreform serta menjamin tanah-tanah yang didistribusikan produktif, namun pelaksanaannya gagal karena Kementerian Kehutanan dan Pertanian tidak menyetujui usulan BPN tersebut.

Kedua, masih berkembangnya sektoralisme kelembagaan dan regulasi dalam penguasaan dan pengelolaan tanah, hutan, dan kekayaan alam lainnya karena tidak menjalankan UUPA tahun 1960. Pelaksanaan reforma agraria bukan hanya dilaksanakan oleh Kementerian Agraria dan Tata Ruang melainkan juga melibatkan kementerian/lembaga lainya. Setiap kementerian/lembaga mempunyai kewenangan untuk membuat kebijakan dalam batasan koridor kerja masing-masing. Akibatnya ketika implementasi tugas dan operasional, masingmasing kementerian/lembaga tersebut seringkali overlap bahkan mengalahkan satu dengan yang lainnya. Ego sektoral ini muncul akibat adanya tuntutan negara kepada masing-masing kementerian/lembaga untuk melaksanakan tugasnya dengan seoptimal mungkin.

Masalah kemiskinan, ketimpangan penguasaan dan kepemilikan tanah serta sulitnya lapangan pekerjaan adalah problem pokok dan mendasar yang dihadapi masyarakat. Kebijakan reforma agraria pada masa pemerintahan Joko Widodo diarahkan untuk mengatasi ketiga masalah tersebut. Setelah menjadikan reforma agraria sebagai program strategi nasional tentunya perlu dibentuk suatu kelembagaan untuk melaksanakan program strategis nasional tersebut. GTRA lahir sebagai bentuk keseriusan pemerintah untuk melaksanakan reforma agraria. GTRA diharapkan dapat menyelesaikan permasalahan ketimpangan penguasaan dan kepemilikan tanah, melaksanakan penataan akses bahkan bisa menjadi cara baru menyelesaikan sengketa-sengketa agraria antara masyarakat dengan perusahaan, antar masyarakat dengan pemerintah.

GTRA dalam menjalankan tugas tentunya tidak mudah. Terdapat tantangan dalam pelaksanaan reforma agraria oleh GTRA. Sebagaimana kita ketahui bahwa GTRA dalam menjalankan tugasnya melibatkan banyak kementerian/lembaga. 
Apabila setiap kementerian/lembaga merasa terlibat dan mendapatkan manfaat, maka kelembagaan GTRA akan berjalan dengan baik dan efektif. Pelibatan berbagai pihak tersebut juga harus didukung dengan tingginya tingkat kepercayaan masing-masing kementerian/lembaga, sehingga hubungan antar pihak dapat berjalan harmonis dan berkesinambungan. Salah satu indikator kelembagaan yang berkelanjutan adalah dengan terciptanya koordinasi, integrasi, dan sinkronisasi. Tantangan lainnya ialah bagaimana membuat GTRA menjadi kelembagaan bersama dalam pelaksanaan reforma agraria. Sebagaimana peneliti ketahui inisiasi pembentukan GTRA adalah dari Kementerian ATR/BPN. Terkait dengan pendanaan juga melalui DIPA kantor pertanahan. Kemudian untuk tugas pelaksana harian GTRA hampir seluruh anggotanya dari pejabat kantor pertanahan. Hal ini tentunya akan menimbulkan persepsi di kementrian/lembaga terkait serta pemerintah daerah bahwasanya GTRA adalah kelembagaan di bawah Kementerian ATR/BPN sehingga kementerian/lembaga terkait serta pemerintah daerah merasa tidak bertanggung jawab dengan capaian kelembagaan ini.

GTRA Kabupaten Lampung Tengah dibentuk berdasarkan Surat Keputusan Bupati Nomor: 427/KPTS/Setda.I.04/2019 tentang Tim Gugus Tugas Reforma Agraria Kabupaten Lampung Tengah. Berdasarkan Peraturan Presiden Nomor 86 Tahun 2018 terdapat sepuluh tugas yang diemban oleh tim GTRA di tingkat kabupaten. Dari Kesepuluh tugas tersebut dapat dikerucutkan menjadi tiga tugas utama. Pertama melaksanakan penataan aset, kedua melaksanakan penataan akses dan yang ketiga memfasilitasi penanganan sengketa dan konflik agraria. Berikut ini akan dibahas kegiatan reforma agraria di Kabupaten Lampung Tengah terkait dengan tiga tugas utama tersebut.

\subsection{Penataan Aset}

Waryanta (2016) menjelaskan penataan aset dapat dilakukan dengan kehadiran negara untuk memberikan tanah kepada masyarakat yang memerlukan maupun penguatan hak kepemilikan atas tanah terhadap tanah-tanah yang telah dikuasai oleh masyarakat. Selanjutnya, Luthfi (2018) juga menyatakan bahwa pelaksanaan reforma agraria menyasar empat kategori tanah yaitu tanah-tanah legalisasi aset, tanah objek reforma agraria (TORA), hutan negara dan pengelolaan serta pengadaan lahan aset desa. GTRA Kabupaten Lampung Tengah dalam melaksanakan reforma agraria menyasar kategori TORA. GTRA Kabupaten Lampung Tengah selanjutnya menargetkan empat lokasi yang akan dijadikan TORA. Lokasi tersebut antara lain:

1) Tanah pelepasan eks HGU PT. Gunung Aji jaya No. U.8 seluas $\pm 92 \mathrm{Ha}$

Permasalahan pada tanah eks HGU PT. Gunung Aji Jaya disebabkan masyarakat yang menguasai sebagian tanah milik PT. Gunung Aji Jaya. Masyarakat Desa Gunung Haji mengklaim telah menguasai tanah tersebut sebelum HGU PT. Gunung Aji Jaya terbit. Tanah yang dikuasai masyarakat berupa tanah pekarangan dan tanah pertanian. Akibatnya, sebagian lokasi 
tanah masyarakat di Desa Gunung Haji yang masuk pada lokasi HGU PT. Gunung Aji Jaya tidak bisa disertifikatkan.

2) Tanah transmigrasi spontan MKGR tahun 1974 yang tidak terdaftar di Dinas Tenaga Kerja dan Transmigrasi seluas $\pm 2000 \mathrm{Ha}$.

Permasalahan utama pada lokasi transmigrasi spontan MKGR tahun 1974 di Desa Sumber Agung dan Sidodadi disebabkan pihak MKGR mengusulkan agar warga yang akan mensertifikatkan tanahnya untuk membayar biaya kompensasi ke MKGR, karena MKGR yang mengurus tanah itu sejak tahun 1970. Sementara itu, kantor pertanahan Kabupaten Lampung Tengah akan melaksanakan pensertifikatan sesuai peraturan dan petunjuk teknis yang ada, tidak boleh ada persyaratan-persyaratan tambahan dari MKGR seperti kartu anggota dan biaya kompensasi. Kemudian dari Dinas Tenaga Kerja dan Transmigrasi menyarankan agar menyelesaikan terlebih dahulu masalahnya antara MKGR dengan warga Desa Sumber Agung dan Desa Sidodadi, selanjutnya mengumpulkan alas hak dan dikoordinasikan dengan Disnakertrans Provinsi dan Kabupaten untuk diusulkan sertifikasinya.g

3) Tanah Transmigrasi Bantuan Presiden (Banpres) 1974 di Desa Sri Mulyo

Permasalahan pada tanah transmigrasi Banpres 1974 terkait dengan 21 KK di Desa Sri Mulyo yang belum mendapatkan bagian tanah pertanian. Pihak Dinas Tenaga Kerja dan Transmigrasi sudah menyiapkan lokasi tanah pertanian dari tanah eks HGU PT. TDA. Namun, tanah eks HGU PT.TDA yang akan diberikan kepada $21 \mathrm{KK}$ di Desa Sri Mulyo telah dikuasai oleh masyarakat. Pihak masyarakat meminta kompensasi jika tanah tersebut mau diambil kembali oleh Dinas Tenaga Kerja dan Transmigrasi. Masyarakat meminta kompensasi dikarenakan mereka memperoleh tanah tersebut dari jual beli.

4) Lokasi SP.3 yang terindikasi masuk dalam kawasan hutan Register 47 Way Terusan

Berdasarkan informasi dari Dinas Tenaga Kerja dan Transmigrasi Provinsi Lampung dan Dinas Tenaga Kerja dan Transmigrasi Kabupaten Lampung Tengah diketahui bahwa lokasi Way terusan SP. 3 seluas $\pm 350 \mathrm{Ha}$ berada pada kawasan Hutan Produksi Tetap Way Terusan Register 47. Gubernur Lampung melalui surat No.591/2241/01/2007 tanggal 31 Oktober 2007 dan surat Nomor 591/0505/01/2008 tanggal 12 Maret 2008 telah menyetujui dilakukan tukar-menukar sisa areal pencadangan seluas $\pm 650 \mathrm{Ha}$ dengan lahan pemukiman transmigrasi SP. 3 seluas $\pm 350 \mathrm{Ha}$. Namun sampai saat ini belum dilaksanakan cek lapangan oleh pihak-pihak terkait terhadap areal pengganti seluas $\pm 650 \mathrm{Ha}$ tersebut.

Pada pelaksanaannya, penyediaan TORA masih belum dilaksanakan secara optimal. Dari empat lokasi yang menjadi target penyediaan TORA, hanya mampu dilaksanakan TORA untuk tanah pelepasan Eks HGU PT. Gunung Aji jaya No. U.8. Berdasarkan hasil survey tim pelaksana harian GTRA 
Kabupaten Lampung Tengah pada lokasi eks HGU PT. Gunung Aji Jaya diperoleh 71 nama yang menguasai tanah seluas $40 \mathrm{Ha}$ yang terdiri atas 21 lokasi tanah pertanian dan 50 lokasi tanah pekarangan. Selanjutnya pada tanggal 1 Agustus 2019 tanah Eks HGU PT. Gunung Aji jaya ditetapkan menjadi TORA oleh Tim GTRA Kabupaten Lampung Tengah.

Pelaksanaan penyediaan TORA belum optimal terjadi karena kegiatan GTRA Kabupaten Lampung Tengah hanya dilakukan untuk tahun anggaran 2019 sehingga kepala kantor pertanahan lebih fokus untuk penyedian TORA pada tanah yang clean and clear. Selain itu untuk 3 lokasi lainya masih terdapat permasalahan yang membutuhkan waktu yang cukup lama dalam penyelesaiannya karena permasalahannya sudah terjadi puluhan tahun melibatkan banyak pihak baik dari instansi pemerintah maupun dari unsur masyarakat.

\subsection{Penataan Akses}

Reforma Agraria merupakan pengejawantahan Nawacita dan amanat RPJMN yang bertujuan sebagai pilar dalam pemerataan ekonomi bangsa yang selalu diupayakan oleh pemerintah pusat maupun daerah dengan kegiatankegiatan yang langsung ditujukan kepada masyarakat, seperti kegiatan redistribusi tanah (penataan aset) dan kegiatan pemberdayaan, sosialisasi, dan pelatihan (penataan akses). Arisaputra (2013) berpendapat bahwa penataan akses berkaitan dengan penataan penggunaan atau pemanfaatan tanah yang lebih produktif disertai penataan dukungan sarana dan prasarana yang memungkinkan petani memperoleh akses ke sumber ekonomi di wilayah pedesaan. Akses tersebut antara lain akses sarana dan prasarana pertanian, pengairan, jalan, usaha tani, pemasaran produksi, koperasi usaha tani, dan perbankan. Pandamdari (2019) juga mengatakan penataan akses dilaksanakan dengan pola pemberian langsung oleh pemerintah, kerjasama antara masyarakat yang memiliki sertifikat hak milik dengan badan hukum melalui program kemitraan yang berkeadilan serta kerja sama antara kelompok masyarakat yang memiliki hak kepemilikan bersama dengan badan hukum melalui program tanah dan penyertaan modal.

Pada tanggal 20 November 2019 Tim Gugus Tugas Reforma Agraria (GTRA) Kabupaten Lampung Tengah telah melaksanakan rapat koordinasi yang dilaksanakan di Hotel BBC Bandar Jaya, Kabupaten Lampung Tengah. Rapat tersebut dihadiri oleh seluruh Tim GTRA Kabupaten Lampung Tengah serta dihadiri oleh perwakilan Desa Gunung Haji Kecamatan Pubian yang merupakan lokasi Tanah Obyek Reforma Agraria (TORA) tahun anggaran 2019. Melalui rapat tersebut dapat disosialisasikan serta didiskusikan terkait dengan usulan pembentukan akses Desa Gunung Haji berupa pembuatan jalan, pelebaran jalan, drainase, pagar makam, penerangan jalan, gapura desa dan pembentukan kelompok usaha bersama kerajinan tenun tapis khas Lampung. 
Selanjutnya, untuk pembuatan dan pelebaran jalan, masyarakat Desa Gunung Haji yang terkena dampak pembuatan dan pelebaran jalan dengan suka rela melepaskan tanahnya. Hal ini dibuktikan dengan surat pernyataan pelepasan sebagian hak atas tanah untuk kepentingan umum yang ditandatangani oleh pemilik tanah, saksi yang terdiri atas Kepala Desa Gunung Haji dan Kepala Seksi Hubungan Hukum Pertanahan Kabupaten Lampung Tengah serta diketahui oleh Kepala Kantor Pertanahan.

Kegiatan penataan akses selanjutnya yang dilaksanakan di Desa Gunung Haji ialah pembentukan kelompok kerajinan membuat kain tenun tapis khas Lampung. Berdasarkan informasi dari Kepala Seksi Penataan Pertanahan, Desa Gunung Haji memiliki sumber daya manusia dibidang pembuatan kain tapis, namun karena keterbatasan alat dan belum adanya sebuah kelompok yang dapat digunakan sebagai wadah penyalur kemampuan tersebut menjadikan kerajinan tapis yang ada di desa tersebut tidak dapat berkembang. Melihat hal tersebut, Tim GTRA Kabupaten Lampung Tengah mengusulkan kepada kelompok pengrajin tenun tapis di Desa Gunung Haji untuk membuat proposal pengajuan bantuan dana kepada Dinas Koperasi dan UKM Kabupaten Lampung Tengah. Berdasarkan informasi dari Kepala Dinas Koperasi dan UKM Kabupaten Lampung Tengah proposal pengajuan dana oleh kelompok Tenun Tapis Gunung Haji Berkarya sudah diteruskan ke Kementerian Koperasi dan UKM untuk ditindaklanjuti.

\subsection{Penyelesaian Konflik}

Konflik agraria adalah bentuk konflik yang sifatnya kompleks dan multidimensi (Mulyani 2014). Menurut Fisher (2001) terkait teori kebutuhan manusia, bahwa konflik yang muncul ditengah masyarakat disebabkan perebutan kebutuhan dasar manusia, seperti kebutuhan fisik, mental dan sosial yang tidak terpenuhi dalam perebutan tersebut. Penyelesaian konflik merupakan bagian dalam pelaksanaan reforma agraria. Menurut Rachman (2013) konflik agraria yang terjadi dimulai dengan pemberian izin/hak pemanfaatan oleh pejabat publik yang mengeksklusi sekelompok rakyat dari tanah, sumber daya alam dan wilayah kelolanya. Berdasarkan data KPA tahun 2018 sebanyak 807.177 Ha tanah dalam status konflik. Sektor perkebunan merupakan penyumbang terbesar konflik di Indonesia dengan jumlah $73 \%$ dari konflik yang ada. Berdasarkan data dari Kementerian Pertanian tahun 2019 luas kebun sawit di Indonesia mencapai 16.381.959 Ha yang sebagian besar dikuasai oleh badan usaha besar. Undang-Undang Nomor 5 tahun 1960 tentang Peraturan Dasar Pokok-Pokok Agraria memang memberikan kekuasaan yang sangat luas kepada negara atas sumber daya agraria dengan konsep yang dikenal dengan hak menguasai oleh Negara (Zakie, 2016). Kemudahan para pemodal untuk menguasai tanah negara lambat laun terakumulasi menjadi ketimpangan struktur agraria. Sementara itu negara seringkali tidak mengakui tanah-tanah yang dikuasai oleh masyarakat di suatu wilayah dari generasi ke generasi. 
Reforma agraria pada masa pemerintahan joko widodo diartikan sebagai bentuk bagi-bagi sertifikat. Pembagian sertifikat selama ini dilakukan terhadap tanah yang clean and clear. Bila tujuan sertifikasi adalah menyelesaikan konflik agraria, sertifikat semestinya diberikan kepada masyarakat yang tanahnya berada dalam konflik agraria. Pada praktiknya, penyelesaian konflik menjadi berlarut-larut karena pemerintah enggan memberikan tanah yang disengketakan kepada masyarakat jika tidak mendapat izin dari perusahaan tersebut. Reforma agraria bisa dijadikan sebagai bentuk atau pilihan dari penyelesaian konflik jika pemerintah mampu melaksanakan sertifikasi pada tanah-tanah yang dalam keadaan konflik. Penyebab terjadinya konflik agraria adalah konsentrasi penguasaan lahan di pedesaan yang dikuasai segelintir pemodal. Reforma agraria bertujuan menguatkan hak atas tanah pertanian desa dan melindungi hak kelompok rentan yang termarginalkan. Konflik dan reforma agraria identik karena keduanya hadir apabila terjadi ketimpangan struktur pemilikan dan penguasaan tanah.

Penyelesaian konflik yang dilaksanakan oleh Tim GTRA Kabupaten Lampung Tengah masih belum optimal. Menurut Kepala Seksi Penanganan Masalah dan Pengendalian Pertanahan Kabupaten Lampung Tengah, Tim GTRA Kabupaten Lampung Tengah tidak melaksanakan penyelesaian sengketa dan konflik agraria disebabkan karena tidak ada usulan dari masyarakat maupun dari pihak lainnya yang terkait dengan konflik agraria. Hal ini disebabkan karena kurangnya sosialisasi dari GTRA baik di pusat maupun di tingkat kabupaten/kota mengenai kewenangan GTRA dalam penyelesaian konflik. Terkait dengan 3 lokasi transmigrasi yang berpotensi konflik juga tidak terselesaikan karena keterbatasan waktu yang hanya satu tahun anggaran. Permasalahan di 3 lokasi transmigrasi tersebut sudah terjadi puluhan tahun dan terdapat permasalahan turunan sehingga membutuhkan banyak waktu untuk penyelesaiannya.

Menurut Kasi Penanganan Masalah dan Pengendalian Pertanahan Kabupaten Lampung Tengah sengketa dan konflik agraria yang ditangani oleh Tim GTRA berkaitan dengan penyediaan TORA dalam rangka pelaksanaan reforma agraria. Selain hal tersebut maka penanganan sengketa dan konflik pertanahan ditangani oleh bidang lima yaitu Seksi Penanganan Masalah dan Pengendalian Pertanahan yang diatur berdasarkan Peraturan Menteri Agraria dan Tata Ruang/ Kepala Badan Pertanahan Nasional Nomor 11 Tahun 2016 Tentang Penyelesaian Kasus Pertanahan. Sampai saat ini peraturan menteri terkait dengan penanganan sengketa dan konflik agraria yang dilaksanakan oleh Tim GTRA belum terbit sehingga masih membingungkan terkait dengan kewenangan penyelesaiannya.

\section{Kendala Pelaksanaan GTRA di Kabupaten Lampung Tengah}

Terdapat beberapa kendala dalam pelaksanaan Gugus Tugas Reforma Agraria Kabupaten Lampung Tengah. Kendala tersebut yaitu: kurangnya pemahaman masyarakat, kurangnya perhatian dari pemerintah daerah dalam 
pelaksanaan penataan akses, kurangnya koordinasi antar linats sektor kelembagaan, serta tidak adanya anggaran dalam pelaksanaan GTRA.

\section{a. Kurangnya Pemahaman Masyarakat}

Secara kelembagaan unsur masyarakat memang tidak dilibatkan secara langsung dalam kelembagaan GTRA di tingkat kabupaten. Namun tidak bisa dipungkiri bahwasannya salah satu kunci suksesnya suatu kegiatan yang dilaksanakan pemerintah berkat partisipasi masyarakat yang aktif dalam mengikuti setiap program yang ada. Kurangnya pemahaman masyarakat terhadap pelaksanaan kegiatan GTRA di Desa Gunung Haji menyebabkan kurangnya berminatnya masyarakat untuk berpartisipasi mendukung kegiatan ini. Ditambah lagi dengan keadaan sosial masyarakat yang sebagian besar bekerja sebagai buruh tani sehingga masyarakat lebih memilih untuk bekerja daripada mengikuti penyuluhan yang diadakan oleh Kantor Pertanahan Kabupaten Lampung Tengah. Berdasarkan informasi dari Kepala Desa Gunung Haji sekitar $75 \%$ masyarakatnya bekerja sebagai buruh tani.

b. Kurangnya Perhatian dari Pemerintah Daerah dalam Pelaksanaan Penataan Akses

Salah satu hambatan dalam pelaksanaan reforma agraria oleh GTRA Kabupaten Lampung Tengah adalah kurangnya perhatian dari pemerintah daerah dalam pelaksanaan penataan akses yang tujuannya untuk meningkatkan perekonomian serta pembangunan khususnya di Desa Gunung Haji. Ada beberapa faktor yang menyebabkan hal ini terjadi. Pertama, reforma agraria bukan prioritas kebijakan pemerintah daerah Kabupaten Lampung Tengah. Hal ini disebabkan kurangnya koordinasi dan antara pemerintah pusat dan pemerintah daerah dalam pelaksanaan reforma agraria yang merupakan program strategis pemerintah pusat. Ditambah lagi ego sektoral daerah yang merasa punya kewenangan lebih untuk mengatur daerahnya sendiri.

Kedua, tidak ada program khusus dari pemerintah daerah dalam hal penataan akses. Menurut Asisten bidang Perekonomian dan Pembangunan Kabupaten Lampung Tengah, kegiatan reforma agraria tidak dimasukan dalam Rencana Pembangunan Jangka Menengah Daerah (RPJMD) sehingga untuk melaksanakan penataan akses berupa bantuan modal atau bantuan lain harus berkoordinasi dengan dinas terkait. Sebagai contoh di Desa Gunung Haji kelompok tenun tapis mengajukan proposal bantuan kepada Dinas Koperasi dan UKM untuk memperoleh bantuan modal.

Ketiga, Kurangnya sosialisasi dari pemerintah pusat kepada pemerintah daerah dalam hal ini presiden langsung mengamanatkan kepada bupati sehingga tidak ada lagi anggapan bahwa reforma agraria adalah program dari Kementerian Agraria dan Tata Ruang melainkan juga program pemerintah daerah. 


\section{c. Kurangnya Koordinasi antara Lintas Sektor Kelembagaan}

Salah satu kunci suksesnya pelaksanaan reforma agraria adalah koordinasi yang efektif antara lintas sektor kelembagaan. Berdasarkan Peraturan Presiden Nomor 86 Tahun 2018 tentang Reforma agraria, pelaksanaan reforma agraria merupakan tugas dari seluruh kelembagaan kementerian ataupun non kementerian serta melibatkan partisipasi masyarakat dan atau akademisi. Pada pelaksanaan reforma agraria oleh GTRA Kabupaten Lampung Tengah, di dalam Surat Keputusan Nomor : 39.Kep-18.03/IV/2019 tentang Tim Pelaksana Harian Gugus Tugas Reforma Agraria Kabupaten Lampung Tengah menyebutkan hanya dua anggota dari pemerintah daerah yang terlibat dalam pelaksanaan harian tugas GTRA. Harusnya di dalam pelaksanaan tugas harian GTRA, juga melibatkan seluruh anggota sehingga pelaksanaan reforma agraria berjalan lebih efektif. Akibatnya terjadi kurang koordinasi antara lintas sektor kelembagaan dalam menjalankan agenda reforma agraria.

\section{d. Tidak Ada Anggaran Pelaksanaan Kegiatan GTRA}

Berdasarkan Peraturan Presiden Nomor 86 Tahun 2018 terkait anggaran pelaksanaan reforma agraria dibebankan pada Anggaran Pendapatan dan Belanja Negara (APBN), Anggaran Pendapatan dan Belanja Daerah (APBD) dan sumber lain sesuai dengan ketentuan peraturan perundang-undangan. Dalam pelaksanaan GTRA di Kabupaten Lampung Tengah terdapat anggaran dari APBN melalui DIPA Kantor Pertanahan Kabupaten Lampung Tengah. Anggaran dari DIPA kantor pertanahan merupakan dana kesekertariatan yang digunakan untuk rapat koordinasi, survey lokasi TORA dan kegiatan kesekertariatan lainnya. Sementara anggaran APBD yang digunakan untuk kegiatan penataan akses tidak ada. Hal ini terjadi karena agenda reforma agraria bukan program prioritas di Kabupaten Lampung Tengah sehingga tidak dimasukan kedalam Rencana Pembangunan Jangka Menengah Daerah (RPJMD). Akibatnya GTRA Kabupaten Lampung Tengah mengalami kesulitan anggaran dalam rangka kegiatan penataan akses.

\section{e. Kendala Teknis}

1) Terdapat penguasaan tanah melebihi batas maksimum.

Berdasarkan survey dari tim pelaksana harian GTRA Kabupaten Lampung Tengah terdapat masyarakat yang memiliki tanah melebihi dari batas maksimum pemilikan tanah. Di dalam Peraturan Presiden Nomor 86 Tahun 2018 pasal 9 ayat 1 menyebutkan bahwa objek redistribusi tanah untuk tanah pertanian diredistribusi kepada subjek reforma agraria dengan luasan paling besar $5 \mathrm{Ha}$ sesuai dengan ketersedian TORA. Sementara di Desa gunung Haji ada 2 warga yang memiliki luasan tanah lebih dari $5 \mathrm{Ha}$. Masyarakat yang menguasai tanah tersebut mengakui memperoleh tanah tersebut dari jual beli yang sudah terjadi puluhan tahun yang lalu. Hal ini menjadi kelemahan tersendiri dari pelaksanaan reforma agraria yang didasari oleh Peraturan Presiden Nomor 86 Tahun 2018 
karena dari awal masyarakat sudah menguasai tanah tersebut sementara Kementrian Agraria dan Tata Ruang hanya melegalisasi apa yang sudah dikuasai masyarakat bukan memberikan tanah kepada petani yang tidak memiliki tanah untuk digarap.

2) Terdapat tanah absentee.

Menurut Kasi Penataan Pertanahan Kabupaten Lampung Tengah terdapat masyarakat yang memiliki tanah di Kampung Gunung Haji, namun berdomisili di luar lokasi tanah tersebut. Hal ini terjadi karena ada masyarakat yang menjual tanah dibawah tangan kepada orang yang berdomisili di luar kecamatan lokasi tersebut. Sebagian juga ada karena pewarisan dari orang tua mengingat tanah tersebut sudah dikuasai masyarakat puluhan tahun. Dampak dari tanah absentee ialah kurang efisiennya penggunaan lahan karena lahan tersebut hanya dijadikan sebagai sarana investasi dan akan dijual kembali setelah harganya tinggi.

\subsection{Solusi Penanganan Kendala}

Dalam pelaksanaan penanganan masalah yang dihadapi tim GTRA, tidak saja menjadi perhatian bagi Kementerian Agraria dan Tata Ruang Badan Pertanahan nasional Kabupaten Lampung Tengah, namun juga menjadi perhatian dari pemerintah daerah dan lembaga tinggi lainnya. Dibutuhkan koordinasi yang sangat baik antar Kementerian/lembaga maupun stakeholder terkait agar pelaksanaan penataan aset dan penataan akses dapat berjalan secara lebih optimal. Adapun langkah-langkah penanganan masalah yang dilaksanakan sebagai berikut:

a. Peran aktif dari Pelaksana Harian GTRA untuk memberikan pemahaman kepada masyarakat dengan mengadakan diskusi ataupun konsultasi terkait pelaksanaan reforma agraria yang dilaksanakan di balai Desa Gunung Haji ataupun menggunakan media komunikasi.

b. Secara aktif menjalin kerja sama dengan stake holder terkait, seperti Dinas Koperasi dan UKM, Dinas Perdagangan, Dinas Perumahan Rakyat dan Kawasan Pemukiman, Dinas Pertanian, Tanaman Pangan dan Holtikultura perlu dilaksanakan dalam rangka penataan akses. Hal ini menjadi penting karena reforma agraria belum dimasukan kedalam RPJMD Kabupaten Lampung Tengah. Harapannya setelah dilaksanakan kerja sama, stake holder terkait bisa memberikan bantuan sesuai dengan program yang ada dimasing-masing kelembagaannya.

c. Terkait dengan kurangnya koordinasi antara lintas sektor kelembagaan dan tidak adanya anggaran pelaksanaan kegiatan GTRA, harusnya dalam hal ini ketua GTRA di tingkat kabupaten yaitu bupati Kabupaten Lampung Tengah berperan aktif mensosialisasikan dan mendorong agenda reforma agraria. Bupati sebagai kepala daerah juga mempunyai kewenangan untuk menjadikan reforma agraria sebagai program khusus pemerintah daerah 
sehingga untuk pendanaan dicantumkan dalam Rencana Pembangunan Jangka Menengah Daerah (RPJMD).

d. Solusi Teknis

1) Sosialisasi Batas Maksimum pemberian TORA

GTRA Kabupaten Lampung tengah selain melaksanakan sosialisasi pelaksanaan GTRA juga melaksanakan sosialisasi mengenai batas maksimum pemberian TORA. Hal ini dilakukan karena terdapat warga yang menguasai tanah pertanian lebih dari $5 \mathrm{Ha}$ sedangkan didalam Peraturan Presiden Nomor 86 Tahun 2018 tentang Reforma Agraria maksimum diberikan 5 Ha sesuai dengan ketersedian TORA. Selanjutnya setelah dilaksanakan sosialisasi, untuk warga yang menguasai tanah kelebihan maksimum diharapkan mau melepaskanya dan selanjutnya akan diredistribusikan kepada subjek reforma agraria sesuai dengan peraturan perundangundangan yang berlaku.

2) Sosialisasi terkait Tanah Absentee

Sosialisasi terakhir yang dilaksanakan oleh tim GTRA Kabupaten Lampung Tengah yaitu mengenai tanah absentee. Di dalam Peraturan Pemerintah Nomor 224 Tahun 1961 pasal 3 menyebutkan bahwa pemilik tanah pertanian yang bertempat tinggal di luar kecamatan tempat letak tanahnya, dalam jangka waktu 6 bulan wajib mengalihkan hak atas tanahnya kepada orang lain di kecamatan tempat letak tanah itu atau pindah ke kecamatan letak tanah tersebut kecuali jarak kecamatannya berbatasan antara pemilik dan tanahnya, sehingga masih dimungkinkan untuk mengerjakan tanah tersebut secara efisien. Berdasarkan peraturan tersebut tim GTRA tetap memasukan subjek TORA yang tanahnya absentee dengan membuat surat pernyataan bermaterai yang menyatakan bahwa pemilik tanah dalam waktu 6 bulan akan berpindah ke kecamatan letak tanah atau dialihkan ke orang lain yang berada di kecamatan letak tanah tersebut.

\section{Analisa Peran GTRA Kabupaten Lampung Tengah}

Secara umum pelaksanaan reforma agraria di Kabupaten Lampung Tengah berjalan dengan cukup baik. Berdasarkan informasi dari Kasi Penataan Pertanahan realisasi anggaran GTRA sebesar $74,67 \%$ dari keseluruhan total anggaran DIPA Kantor Pertanahan Kabupaten Lampung Tengah. Ada beberapa catatan yang cukup penting yang perlu dibahas agar pelaksanaan reforma agraria khususnya di Kabupaten Lampung Tengah berjalan lebih baik lagi. Pertama terkait dengan anggaran pelaksanaan. Anggaran pelaksanaan GTRA Kabupaten Lampung Tengah hanya dibebankan DIPA Kantor Pertanahan. Padahal GTRA Kabupaten Lampung Tengah diketuai oleh bupati akan tetapi tidak ada anggaran khusus dari pemerintah daerah untuk pelaksanaan GTRA Kabupaten Lampung Tengah. Jika dilihat dari Peraturan Presiden Nomor 86 Tahun 2018 Pasal 27, terkait dengan pendanaan, dibebankan pada APBN dan APBD serta sumber lain yang sah sesuai ketentuan peraturan perundang- 
undangan. Selanjutnya, apabila kita merujuk pada pelaksanaan GTRA di Kabupaten Sanggau yang dikategorikan berhasil, reforma agraria menjadi program khusus pemerintah daerah sehingga pendanaan dicantumkan pada RPJMD Kabupaten Sanggau. Hal ini tentunya biasa dijadikan rujukan dalam pelaksanaan GTRA di tingkat kabupaten sebagai bukti keseriusan pemerintah daerah untuk mendukung kegiatan reforma agraria.

Kedua mengenai realisasi capaian GTRA Kabupaten Lampung Tengah. Dari keempat lokasi tersebut hanya pelepasan tanah eks HGU PT. Gunung Aji Jaya No. U.8 seluas \pm 92 Ha yang terealisasi. Menurut Kepala Kantor Pertanahan Kabupaten Lampung Tengah hal ini terjadi karena keterbatasan waktu pelaksanaan yang hanya satu tahun anggaran sehingga Tim GTRA Kabupaten Lampung Tengah terfokus pada lokasi yang dalam penyelesaiannya tidak membutuhkan waktu yang berlarut-larut. Penyelesaian permasalahan agraria bukanlah suatu hal yang mudah untuk diselesaikan. Apalagi permasalahan tersebut telah terjadi puluhan tahun dan juga menimbulkan masalah baru. Butuh waktu yang cukup panjang dan konsistensi dari Tim GTRA untuk menyelesaikan masalah tersebut.

Ketiga, Penataan akses yang belum optimal. Penataan akses merupakan bagian yang tidak bisa dipisahkan dalam pelaksanaan reforma agraria. Pelaksanaan penataan akses di Desa Gunung Haji belum optimal disebabkan oleh karena agenda reforma agraria tidak menjadi program khusus pemerintah daerah yang dimasukan ke dalam Rencana Pembangunan Jangka Menengah Daerah (RPJMD) sehingga kegiatan penataan akses yang sejatinya membutuhkan dana yang besar tidak hanya mengandalkan dana dari pemerintah pusat tetapi juga dana dari pemerintah daerah.

Kegiatan yang dilaksanakan oleh Tim GTRA Kabupaten Lampung Tengah masih sebatas pembentukan organisasi, infrastruktur dan pembinaan sementara kegiatan permodalan, kemitraan dan pemasaran belum berjalan. Seharusnya dengan adanya petunjuk teknis pemberdayaan hak atas tanah masyarakat dapat mempermudah Tim GTRA untuk melaksanakan kegiatan-kegiatan yang seharusnya dilaksanakan dalam rangka penataan penataan akses. Menurut Rohman (2019) penataan akses merupakan sebuah proses menjadi bukan sekedar proses instan dimana di dalamnya terdapat 3 tahapan yaitu penyadaran, pengkapasitasan dan pendayaan.

Keempat terkait dengan penerima TORA yang melebihi batas maksimum. Hal ini terjadi karena proses pemberian tanahnya tidak dibagi oleh tim GTRA melainkan didasarkan pada riwayat penguasaan tanahnya. Objek TORA merupakan tanah pelepasan HGU dan telah dikuasai masyarakat selama puluhan tahun. Selanjutnya, Tim GTRA hanya melegalisasi tanah yang sudah dikuasai masyarakat. Dasar penetapan subjek tanah adalah surat pernyataan penguasaan fisik bidang tanah. Proses ini mirip sekali dengan kegiatan legalisasi aset yang sekarang disebut Pendaftaran Tanah Sistematik Lengkap (PTSL). Hal ini tentunya sangat bertentangan dengan Peraturan Presiden Nomor 86 tahun 2018 Pasal 9 yang menyebutkan bahwa objek redistribusi tanah diberikan kepada subjek reforma agraria maksimal 5 Ha sesuai dengan ketersedian TORA. 
Kelima terdapat subjek yang menolak disertifikatkan walaupun tanahnya sudah ditetapkan menjadi TORA oleh Tim GTRA Kabupaten Lampung Tengah. Data daftar nama awal yang ditetapkan oleh Tim GTRA terdiri atas 71 bidang tanah yang selanjutnya ditetapkan menjadi TORA. 71 bidang tanah tersebut terdiri atas 21 lokasi tanah pertanian dan 50 lokasi tanah pekarangan. Selanjutnya setelah dilaksanakan identifikasi lagi oleh PPL, hasilnya terdapat 73 bidang tanah yang akan disertifikatkan melalui kegiatan redistribusi tanah. 73 bidang tanah tersebut terdiri atas 57 bidang tanah pekarangan dan 16 bidang tanah pertanian. Menurut Kasi Penataan Pertanahan Kabupaten Lampung Tengah terjadi perbedaan daftar nama awal yang ditetapkan oleh GTRA dan daftar nama akhir yang ditetapkan oleh PPL karena ada bidang tanah yang belum terdata dan ada juga yang menolak disertifikatkan. Warga yang menolak beralasan karena terdapat permasalahan keluarga sehingga masih belum jelas siapa yang akan menguasai tanah tersebut. Kemudian ada juga yang menolak pensertifikatan tanahnya karena batasan yang diberikan oleh PPL untuk disertifikatkan seluas $2 \mathrm{Ha}$ sementara mereka menguasai lebih dari $2 \mathrm{Ha}$. Masalah-masalah teknis seperti ini seharusnya tidak terjadi apabila TORA tersebut diredistribusikan sesuai dengan Peraturan Pemerintah Nomor 224 Tahun 1961 dengan memberikan ganti kerugian. Terhadap TORA hasil pelepasan HGU PT. Gunung Aji Jaya di Desa Gunung Haji yang tidak disertifikatkan status tanahnya adalah tanah negara namun tetap dikuasai masyarakat yang menggarapnya.

Beberapa catatan penting di atas mengindikasi bahwa pelaksanaan reforma agraria oleh Tim GTRA Kabupaten Lampung Tengah masih belum optimal. Sejatinya GTRA diharapkan dapat berbuat lebih banyak dalam pelaksanaan reforma agraria dengan melibatkan berbagai lintas sektor kementerian/lembaga malah berkutat pada ego sektoral masing-masing. Belum lagi permasalahan subjek reforma agraria yang menolak disertifikatkan tanahnya karena ada masalah keluarga sehingga masih belum jelas siapa pemiliknya. Ditambah lagi permasalahan dalam pelaksanaan penataan aset terkait objek TORA terdapat tanah absentee dan kelebihan maksimum.

\section{GTRA, PPL dan PPAN}

Gugus Tugas Reforma Agraria (GTRA) merupakan suatu kelembagaan yang dibentuk untuk mendukung pelaksanaan reforma agraria melalui penataan aset disertai penataan akses. GTRA itu sendiri diatur dalam Peraturan Presiden Nomor 86 Tahun 2018 Tentang Reforma Agraria. Sebelum adanya GTRA pelaksanaan reforma agraria dilaksanakan oleh Panitia Pertimbangan Landreform (PPL). PPL diatur di dalam Keputusan Presiden Nomor 55 Tahun 1980 tentang Organisasi dan Tata Kerja Penyelenggaraan Landreform. Terkait dengan keanggotaannya baik GTRA dan PPL di tingkat kabupaten diketuai oleh bupati. 
Berdasarkan Peraturan Presiden Nomor 86 Tahun 2018, GTRA di tingkat kabupaten mempunyai tugas melaksanakan penataan aset, penataan akses dan penyelesaian konflik. Sementara untuk PPL yang diatur di dalam Keputusan Presiden Nomor 55 Tahun 1980 mempunyai tugas melaksanakan penataan aset. Pelaksanaan penataan aset yang dilaksanakan oleh GTRA awalnya dengan cara penyedian TORA. Selanjutnya TORA yang sudah ditetapkan oleh GTRA dilaksanakan penataan aset dengan cara redistribusi tanah atau legalisasi aset sesuai dengan objek tanah yang ditetapkan menjadi TORA. Sementara PPL melaksanakan penataan aset hanya untuk kegiatan redistribusi tanah. PPL selanjutnya melakukan sidang Panitia Pertimbangan Landreform untuk tanah yang sudah ditetapkan menjadi tanah objek landreform (TOL).

Menurut Kasi Penataan Pertanahan Kabupaten Lampung Tengah, penataan aset yang dilakukan oleh PPL umumnya dilaksanakan pada tanah objek landreform yang sudah jelas (clean and clear). Sedangkan GTRA melaksanakan penataan aset pada tanah objek reforma agraria yang terdapat permasalahan yang akan dicarikan solusi penyelesaiannya. Dalam pelaksanaan GTRA di Kabupaten Lampung Tengah, untuk lokasi yang sudah ditetapkan menjadi TORA maka dilaksanakan redistribusi tanah oleh PPL Kabupaten Lampung Tengah. Jadi, terjadi tumpang tindih tugas yang seharusnya dilaksanakan oleh GTRA tetapi dilaksanakan oleh PPL. Hal ini terjadi karena belum jelasnya eksistensi PPL di hadapan GTRA.

Berdasarkan informasi dari Kepala Subseksi Landreform dan Konsolidasi Tanah, pelaksanaan GTRA Kabupaten Lampung Tengah hanya dilaksanakan untuk tahun anggaran 2019 sementara PPL Kabupaten Lampung Tengah dilaksanakan setiap ada kegiatan redistribusi tanah. Terkait dengan Surat Keputusan Bupati dalam rangka pembentukan GTRA dan PPL tidak perlu diperbarui setiap tahun melainkan diperbarui apabila ada perubahan nomenklatur kelembagaan atau instansi terkait.

Selanjutnya, jika melihat dari tugas GTRA di dalam Peraturan Presiden Nomor 86 Tahun 2018 tentang Reforma Agraria yang menyebutkan salah satu tugas GTRA ialah mewujudkan kepastian hukum dan legalisasi hak atas TORA. Sementara pada pelaksanaanya di Kabupaten Lampung Tengah untuk mewujudkan kepastian hukum atas TORA dilaksanakan oleh PPL dengan kegiatan redistribusi tanah. Hal ini menyebabkan terjadinya tumpang tindih tugas antara GTRA dan PP. Terjadinya tumpang tindih tugas GTRA dan PPL karena kegiatan redistribusi tanah menggunakan Petunjuk Teknis Landreform Tahun 2019 yang mana tugas tersebut memang dilaksanakan oleh PPL. Sementara Peraturan Menteri yang mengatur ketentuan lebih lanjut terkait dengan mekanisme dan tatakerja baik GTRA pusat, provinsi dan kabupaten/kota sampai saat ini belum ada.

GTRA di tingkat kabupaten mempunyai tugas utama yaitu melaksanakan penataan aset, penataan akses dan memfasilitasi penanganan konflik agraria. 
Dari sisi kewenangan, GTRA mempunyai peran besar dalam pelaksanaan reforma agraria. Namun pada pelaksanaannya, GTRA membutuhkan waktu dalam menyelesaikan permasalahan agraria yang begitu kompleks dan melibatkan lintas sektor kementerian atau lembaga terkait. Belum lagi konflik agraria sudah terjadi bertahun-tahun lamanya sehingga sangat tidak relevan apabila GTRA hanya dilaksanakan untuk satu tahun anggaran.

Sebagai contoh GTRA Kabupaten Lampung Tengah tahun 2019 yang awalnya menargetkan 4 lokasi untuk difasilitasi dalam penyelesaian permasalahan agraria dan selanjutnya akan ditetapkan menjadi TORA, akhirnya hanya menyelesaikan 1 lokasi saja yaitu di Desa Gunung Haji dengan permasalahan penguasaan tanah oleh masyarakat atas tanah HGU PT. Gunung Aji Jaya sebanyak 71 bidang tanah. Sementara PPL Kabupaten Lampung Tengah pada tahun 2019 telah melaksanakan redistribusi tanah sebanyak 3.818 bidang tanah. Selanjutnya untuk tahun 2020 GTRA Kabupaten Lampung Tengah tidak ada dan PPL Kabupaten Lampung Tengah menargetkan 2.971 bidang tanah yang akan di redistribusikan kepada masyarakat di lima desa. Apabila dilihat dari produktivitasnya dalam melaksanakan redistribusi tanah maka GTRA tertinggal jauh dari PP.

Dari uraian di atas, untuk lebih jelasnya perbedaan GTRA dan PPL peneliti menyajikannya dalam bentuk tabel berikut ini :

Tabel 1. Perbedaan GTRA dan PPL di Tingkat Kabupaten

\begin{tabular}{|c|c|c|c|}
\hline No & Perbedaan & GTRA & PPL \\
\hline 1. & Keanggotaan & $\begin{array}{l}\text {-Seluruh unsur pemerintah } \\
\text { daerah di tingkat } \\
\text { kabupaten/kota } \\
\text {-BPN di tingkat kabupaten } \\
\text { /kota } \\
\text {-Unsur Kehutanan di tingkat } \\
\text { kabupaten/kota } \\
\text {-Kepala Badan Pengelolaan } \\
\text { Keuangan dan aset daerah } \\
\text { (BPKAD) kabupaten/kota } \\
\text {-Kepala BPKH provinsi } \\
\text {-Unsur masyarakat dan atau } \\
\text { akademisi. }\end{array}$ & $\begin{array}{l}\text {-Dinas Tenaga Kerja dan } \\
\text { Transmigrasi } \\
\text {-Dinas Pertanian } \\
\text {-Dinas Koperasi dan UKM } \\
\text {-Dinas Lingkungan Hidup } \\
\text {-BPN di tingkat } \\
\text { kabupaten/kota } \\
\text {-Unsur Kehutanan tingkat } \\
\text { kabupaten/kota } \\
\text {-Kepala Kepolisian Resort } \\
\text { Kabupaten/kota } \\
\text {-Ketua Himpunan Kerukunan } \\
\text { Tani Indonesia (HKTI) } \\
\text { kabupaten/kota }\end{array}$ \\
\hline 2. & Tugas & $\begin{array}{l}\text { Penataan aset, penataan akses } \\
\text { dan memfasilitasi penyelesaian } \\
\text { konflik agraria }\end{array}$ & Penataan Aset \\
\hline 3. & $\begin{array}{l}\text { Waktu } \\
\text { Pelaksanaan }\end{array}$ & 1 Tahun Anggaran & $\begin{array}{l}\text { Setiap ada kegiatan } \\
\text { redistribusi tanah }\end{array}$ \\
\hline 4. & Dasar Hukum & $\begin{array}{l}\text { Peraturan Presiden Nomor } 86 \\
\text { Tahun } 2018\end{array}$ & $\begin{array}{l}\text { Keputusan Presiden Nomor } 55 \\
\text { Tahun } 1980\end{array}$ \\
\hline
\end{tabular}




\begin{tabular}{lll}
\hline 5. Penataan Aset & $\begin{array}{l}\text { Tanah Objek Reforma Agraria } \\
\text { yang terdapat permasalahan } \\
\text { yang akan dicarikan solusi } \\
\text { penyelesaiannya }\end{array}$ & $\begin{array}{l}\text { Tanah Objek Landreform (TOL) } \\
\text { yang sudah jelas (clean and } \\
\text { clear). }\end{array}$ \\
\end{tabular}

Sumber : Hasil Olahan Peneliti, 2020

Pada tabel perbedaan antara GTRA dan PPL di atas, dapat dilihat bahwa GTRA di tingkat kabupaten lebih efektif dalam pelaksanaan reforma agraria. Di sisi keanggotaan GTRA di tingkat kabupaten memiliki keanggotaan yang lebih komplek dibandingkan PPL sehingga dalam melaksanakan tugasnya dapat mempermudah koordinasi antara stakeholder terkait mengingat bahwa permasalahan agraria melibatkan banyak stakeholder. Selanjutnya dari sisi kewenangan, GTRA memiliki kewenangan lebih besar dibandingkan PPL yaitu melaksanakan penataan aset, penataan akses dan memfasilitasi penyelesaian konflik agraria sementara PPL hanya melaksanakan penataan aset.

Pelaksanaan reforma agraria sebelum masa pemerintahan Joko Widodo juga dilaksanakan dengan nama Program Pembaruan Agraria Nasional (PPAN). PPAN adalah program reforma agraria yang dijadikan bagian penting dari agenda pembangunan nasional pada masa pemerintahan Susilo Bambang Yudhoyono (Shohibuddin \& Salim, 2012). PPAN dikomandoi oleh BPN RI kemudian pelaksanaannya dilaksanakan BPN di tingkat kabupaten. Kegiatan PPAN dilaksanakan melalui penataan aset dan penataan akses. Kegiataan penataan aset melibatkan pihak lain seperti pemerintah daerah dan pihak swasta. Kelemahan program ini yaitu tidak dibentuk suatu kelembagaan yang mengatur kegiatan reforma agraria pada tahap perencanaan, pelaksanaan dan pengendalian (Shohibuddin, dkk 2007).

PPAN, PPL dan GTRA ketiganya merupakan program dan kelembagaan reforma agraria yang telah dijalankan di Kabupaten Lampung Tengah. Jika dilihat dari efektivitasnya dalam melaksanakan penataan aset di Kabupaten Lampung Tengah. Ketiganya sama-sama melaksanakan penataan aset pada lokasi tanah yang sejak awal dikuasai masyarakat. Jadi PPAN, PPL dan GTRA hanya meningkatkan status tanah yang dikuasai masyarakat. Kemudian jika dilihat dari efektifitas dalam pelaksanaan penataan akses, PPAN dan GTRA melaksanakan penataan akses bekerja sama dengan pemerintah daerah dan pihak swasta. Sementara PPL tidak melaksanakan penataan akses. Kemudian dari sisi kekuatan baik PPAN, PPL dan GTRA didukung oleh kementerian/lembaga terkait. Hanya saja disini GTRA memiliki dukungan lebih menyeluruh dari kementerian/lembaga terkait. Selanjutnya terkait dengan kelemahan, di dalam PPAN tidak dibentuk suatu kelembagaan yang mengatur kegiatan reforma agraria pada tahap perencanaan, pelaksanaan dan pengendalian. Hal ini penting agar pelaksanaan reforma agraria berjalan dengan efektif dan untuk menangkal berbagai intervensi dari kepentingan politik. Sementara PPL hanya melaksanakan penataan aset. Sementara kelemahan GTRA yaitu sulit untuk menyatukan seluruh kementerian/lembaga terkait untuk bersama-sama melaksanakan kegiatan reforma agraria. 


\section{Kesimpulan}

1. Kesimpulan

Pelaksanaan reforma agraria oleh GTRA di Kabupaten Lampung Tengah masih kurang optimal karena karena keterbatasan anggaran dan adanya ego sektoral kelembagaan serta kurangnya komitmen yang kuat dari seluruh pelaksana GTRA. Terkait dengan kewenangan GTRA di dalam Peraturan Presiden Nomor 86 Tahun 2018 yaitu melaksanakan penataan aset, penataan akses dan memfasilitasi penyelesaian konflik agraria, dalam pelaksanaannya di Kabupaten Lampung Tengah hanya dilaksanakan penataan aset dan penataan akses. Terkait dengan penyelesaian konflik agraria tidak dilaksanakan karena tidak ada usulan dari masyarakat dan pihak lain yang terkait.

Kendala yang dihadapi GTRA Kabupaten Lampung Tengah dalam pelaksanaan reforma agraria yaitu kurangnya pemahaman masyarakat terhadap pelaksanaan kegiatan Gugus Tugas Reforma Agraria (GTRA), belum maksimalnya perhatian dari dinas-dinas terkait kepada Desa Gunung Haji dalam rangka kegiatan penataan akses, kurangnya koordinasi antara lintas sektor kelembagaan, tidak ada anggaran pelaksanaan kegiatan GTRA dan adanya kendala teknis yaitu terdapat penguasaan tanah melebihi batas maksimum dan terdapat tanah absentee pada lokasi sudah ditetapkan menjadi TORA.

Solusi GTRA Kabupaten Lampung Tengah dalam mengatasi kendala dalam pelaksanaan reforma agraria antara lain peran aktif dari pelaksana harian GTRA untuk memberikan pemahaman kepada masyarakat dengan mengadakan diskusi ataupun konsultasi terkait pelaksanaan reforma agraria yang dilaksanakan di balai Desa Gunung Haji ataupun menggunakan media komunikasi kemudian secara aktif menjalin kerja sama dengan stake holder terkait, dalam rangka kegiatan penataan akses. Selanjutnya, Bupati Kabupaten Lampung Tengah berperan aktif mensosialisasikan dan mendorong agenda reforma agraria serta menjadikan reforma agraria sebagai program khusus pemerintah daerah sehingga untuk pendanaan dicantumkan dalam Rencana Pembangunan Jangka Menengah Daerah (RPJMD) serta sosialisasi batas maksimum pemberian TORA dan tanah absentee.

2. Saran

a. Kepada Tim GTRA Kabupaten Lampung Tengah perlu ditingkatkan lagi komunikasi, koordinasi dan sinergi antara pihak-pihak terkait atau stakeholder agar pelaksanaan reforma agraria berjalan lebih optimal. Kemudian, sebaiknya pelaksanaan GTRA di Kabupaten Lampung Tengah dilaksanakan berkelanjutan mengingat masih banyak permasalahan agraria yang bisa dijadikan potensi TORA di Kabupaten Lampung Tengah.

b. Kepada Pemerintah Daerah Kabupaten Lampung Tengah sebaiknya agenda reforma agraria yang menjadi program strategis pemerintah pusat dijadikan program khusus pemerintah daerah yang dimasukan kedalam Rencana Pembangunan Jangka Menengah Daerah (RPJMD) sehingga kegiatan 
penataan akses yang selama ini kurang mendapat perhatian menjadi lebih maksimal pelaksanaannya.

c. Kepada Kantor Pertanahan Kabupaten Lampung Tengah agar konsisten melaksanakan sosialisasi terkait dengan pelaksanaan reforma agraria khususnya dalam penyelesaian konflik sehingga masyarakat nantinya dapat mengusulkan lokasi-lokasi yang terdapat konflik agraria agar segera diselesaikan.

d. Kepada Kementerian Agraria dan Tata Ruang Badan Pertanahan Nasional untuk segera mengeluarkan Peraturan Menteri terkait dengan mekanisme dan tata kerja GTRA agar tidak terjadi tumpang tindih tugas antara GTRA dan PPL.

\section{Daftar Pustaka}

Arisaputra, M.I. (2013). 'Penerapan prinsip-prinsip good governance dalam penyelenggaraan reforma agraria di Indonesia'. Yuridika, 28 (2), 188-216.

Atim, P. (2008). 'Pelaksanaan Reforma Agraria di Provinsi Lampung', Skripsi, Sekolah Tinggi Pertanahan Nasional.

Fisher, S., dkk. (2001). Mengelola konflik keterampilan dan strategi untuk bertindak, The British Council, Jakarta.

Kantor Staf Presiden. (2016). 'Pelaksanaan reforma agraria, arahan kantor staf presiden: prioritas nasional reforma agraria dalam rencana kerja pemerintah tahun 2017', Jakarta.

Luthfi, A.N. (2018). 'Reforma kelembagaan dalam kebijakan reforma agraria era joko widodo-jusuf kalla'. Bhumi, Jurnal Agraria dan Pertanahan, 4 (2), 141-142.

Mulyani, L. (2014). 'Kritik atas penanganan konflik agraria di Indonesia', BHUMI: Jurnal Agraria dan Pertanahan, STPN, Yogyakarta.

Nurlinda, I. (2009). Prinsip-prinsip pembaruan agraria: perspektif hukum, Raja Grafindo Persada, Jakarta.

Pandamdari, E. (2019). 'Harapan sejahtera dan adil melalui peraturan presiden nomor 86 tahun 2018 tentang reforma agraria', Hukum Pidana dan Pembangunan Hukum, 1 (2), 1-6.

Rachman, N.F. (2013). 'Rantai penjelas konflik-konflik agraria yang kronis, sistemik dan meluas', Bhumi Jurnal Agraria dan Pertanahan, 37 (12), 1-14.

Rohman, M.L. (2019). 'Access reform dalam program reforma agraria : studi kasus desa tahunan kecamatan tahunan Kabupaten Jepara', Journal of Politic and Government Studies, 8(4), 381-390.

Salim, M.N \& Utami, W. (2019). Reforma agraria menyelesaikan mandat konstitusi, STPN Press, Yogyakarta.

Shohibuddin, M. dkk. (2007). 'Laporan penelitian pelaksanaan uji coba program pembaharuan agraria nasional di provinsi lampung', Sekolah Tinggi Pertanahan Nasional, Yogyakarta. 
Shohibuddin, M. \& Salim, M.N. (2012). Pembentukan Kebijakan Reforma Agraria, 2006-2007: Bunga Rampai Perdebatan. STPN Press: Yogyakarta

Waryanta, M. ( 2016). 'Reforma agraria : momentum mewujudkan kemandirian ekonomi masyarakat kecil dalam mendukung ketahanan pangan', BHUMI Jurnal Agraria dan Pertanahan, 2(2), 179-193.

Wiradi, G. (2000.) Reformasi Agraria; Perjalanan Yang Belum Berakhir, INSIST Press, Yogyakarta.

Zakie, M. (2016). 'Konflik agraria yang tak pernah reda', Legality Jurnal IImiah Hukum, 24 (1), 40-55.

\section{Peraturan Perundang-Undangan}

Undang-Undang Nomor 5 Tahun 1960 Tentang Peraturan Dasar Pokok-Pokok Agraria.

Peraturan Pemerintah Nomor 224 Tahun 1961 tentang Pelaksanaan Pembagian Tanah dan Pemberian Ganti Kerugian.

Peraturan Presiden Nomor 45 Tahun 2016 tentang Rencana Kerja Pemerintah (RKP) Tahun 2017.

Peraturan Presiden Nomor 86 Tahun 2018 Tentang Reforma Agraria.

Keputusan Presiden Nomor 55 Tahun 1980 tentang Organisasi dan Tata Kerja Penyelenggaraan Landreform.

Keputusan Presiden Nomor 131 Tahun 1961 Tentang Organisasi Penyelenggaraan Landreform.

Keputusan Presiden Nomor 263 Tahun 1964 Tentang Penyempurnaan Panitia Landreform Sebagaimana Termaksud Dalam Keputusan Presiden Nomor 131 Tahun 1961.

Peraturan Menteri Agraria dan Tata Ruang/ Kepala Badan Pertanahan Nasional Nomor 11 Tahun 2016 Tentang Penyelesaian Kasus Pertanahan.

Petunjuk Teknis Kegiatan Landreform Tahun 2019.

Petunjuk Teknis Pemberdayaan Hak Atas Tanah Masyarakat dalam Skema Akses Mengikuti Aset atau dalam Skema Aset Mengikuti Akses Tahun 2019. 